\title{
Variations in Pressuremeter Testing Results
}

\author{
Radhi Alzubaidi
}

\begin{abstract}
Some problems of measuring untrained strength and deformation properties for glacial till are presented. These soils are stiff and have low compressibility. Because of their strong fissured character, satisfactory sampling for laboratory testing presents great practical problems. A number of new pressuremeter suitable for testing glacial till in situ with constant rate of membrane expansion are carried out. The results of insitu horizontal total at rest stress, at rest earth pressure ratio, limit pressure, Undrained shear strength and Elastic Modulus for four sites in Glasgow till deduced from pressuremeter tests using different methods are presented Long time delays between completion of boring and pressuremeter testing produce considerable effects on the undrained parameters of the clay soils. The undrained shear strength, modulus of deformation and limit pressure showed appreciable reductions while the horizontal at rest pressure increases with time. A special tool was developed for extracting samples from the sidewall of the borehole so that moisture content changes can be monitored.
\end{abstract}

Index Terms-Pressuremeter, horizontal at rest pressure, undrained shear strength, elastic modulus, moisture content.

\section{INTRODUCTION}

Soil sample set up for testing in the laboratory have already been subjected to a number of disturbance effects like boring operation, act of sampling, transport, removal from the sampler, stress relief and trimming and others .There is much to be said in favor of testing soils insitu when many of these disturbance effects are eliminated. It will be often be possible to test insitu a larger and hence more representative volume of the soil. The pressuremeter seems to be one of the promising instu tests which received a greet development in both technical aspects and theoretical modifications. Geotechnical design methods have evolved to be in harmony in the results reviewed mainly from laboratory testing. Opportunity for confirmation of the design methods and of the testing, together or separately by measuring and back analyzing the yielding of prototype of structures is infrequent. This may blunt the need for obtaining truly representative values of shear parameters unless one separates the assumptions of the design methods from the soil parameters adopted in applying the methods. [1] investigated into the effect of disturbance occurred during drilling of the boreholes for conducting pressuremeter tests and their effects on interpreted results of the tests Tarnawski concluded that the

Manuscript received February 8, 2016; revised May 23, 2016. Radhi Alzubaidi is with University of Sharjah, Civil and Environmental Engineering, Sharjah, UAE (e-mail: ralzubaidi@sharjah.ac.ae) cause of disturbance to the borehole wall produces unsatisfactory shape of pressuremeter curves. [2] carried out Cambridge self-boring pressuremeter tests in sensitive Champlain clay of Quebec, the results of the undrained shear strength deduced from the pressuremeter were higher than those obtained from the vane tests. Silvestre used the iterative forward modeling (IFM) technique to obtain linearly elastic - perfectly plastic soil parameters by constraining the fit to match the initial horizontal pressure. [3] concluded that four mechanical parameters have an influence on the conventional limit pressure, these parameters are the vertical stress, shear modulus ,shear strength and Ko. [4] conducted pressuremeter tests in clays in different sites in Algeria .They used three methods to evaluate the undrained shear strength of the clay. They concluded that the values of the undrained shear strength that evaluated by the method developed by [5] are higher than those evaluated using the methods that developed by [6] and that developed by [7], [8] investigated into Tianjin Binhai New Area using Cambridge self-boring pressuremeter to interpretate the values of Po (horizontal at rest pressure) using the inflection point method and graphical iteration method .They concluded that using the inflection point method and the graphical iteration method to deduce the values of Po were effective methods for project practice. Due to importance values of the undrained shear strength, modulus of deformation and limit pressure that deduced from pressuremeter testing, a considerable investigation carried out on Glacial till soil to show the effects of delays between completion of boring and pressuremeter testing on undrained parameters.

\section{EfFect OF Delays IN Testing Times ON THE UNDRAINRED PARAMETERS}

Ref. [9]carried out pressuremeter tests on clay soils ,the tests been conducted at different times delays after boring the boreholes in order to explore the effect of delay times on the undrained parameters. The delay times between boring and testing are considered as follows:

(1) Two hours

(2) One day

(3) One week

The tests were carried out on the same site at the same depths all at $2 \mathrm{~m}$ depths. Four tests were carried out after two hours delays, five tests carried out after one day and five tests were carried out after one week, a typical P-V curve for all type of pressuremeter tests are shown in Fig. 1 . These are seen in ascending order of steepness. Also another ordinary set of tests been conducted after $20 \mathrm{~min}$. after boring the boreholes. 


\section{The Horizontal At Rest Pressure $\left(P_{\mathrm{O}}\right)$}

The values of $P_{\mathrm{o}}$ were deduced using the up side down curve method developed by[10], the values of for twenty minutes ,two hours, one day and one week are shown in Fig. 2 , the results showed no distinctive differences between those deduced from two hours and one day than those deduced from twenty minutes, but the results showed a considerable increase been shown in the values of $P_{\mathrm{o}}$ for one week than those obtained from two tests.

\section{The Undrained Shear Strength (CU)}

The values of the undrained shear strength evaluated using the Gibson and Anderson (1961) method as can be shown in Fig. 3 the results of the $\mathrm{Cu}$ for twenty minutes and two hours tests yielded no distinctive differences. The values of $\mathrm{Cu}$ deduced from one day and one weeks tests showed lower values of $\mathrm{Cu}$ than those evaluated from two hour tests.

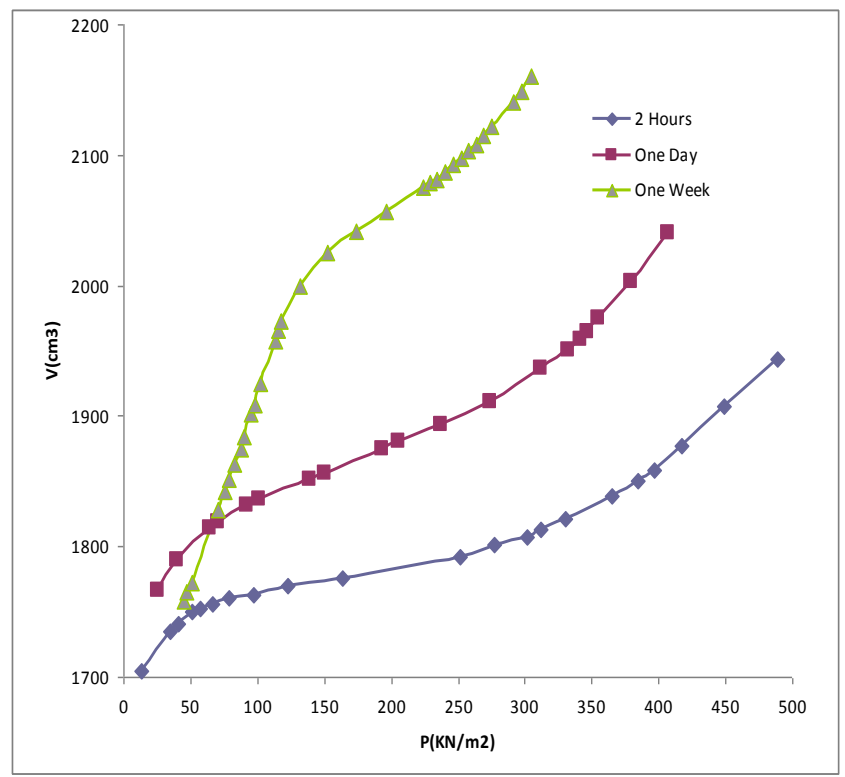

Fig. 1. P-V curve for different time delays pressuremeter testing.

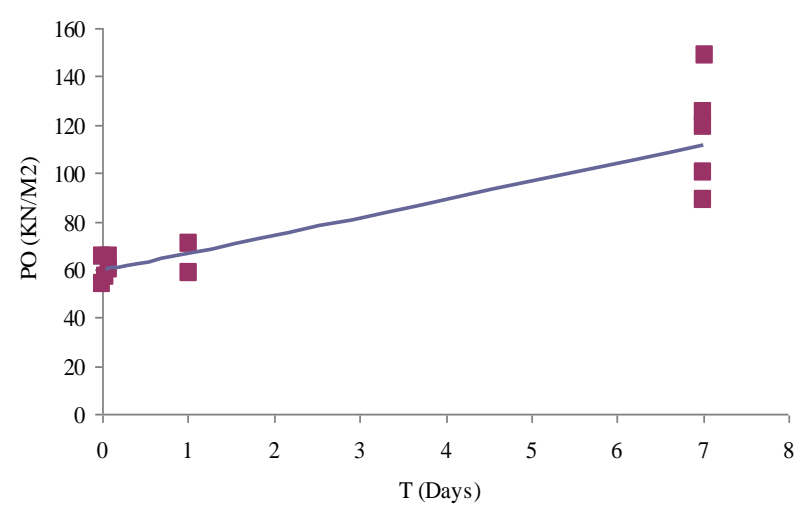

Fig. 2. Variation of Po with time delay.

\section{The Elastic Modulus (EP)}

The values of Ep evaluated using Gibson and Anderson (1961) method, the results as shown in Fig. 4 that the deduced results from twenty minutes and two hours tests showed no significant differences in Ep values. The results of Ep evaluated from one day and one weeks showed a distinctive decrease than those evaluated from twenty minutes tests.

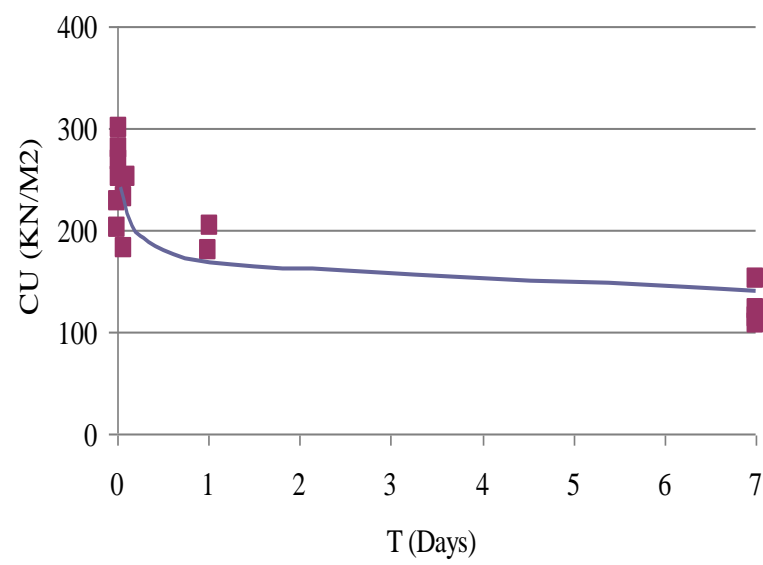

Fig. 3. Variation of the undrained shear strength with time delay.

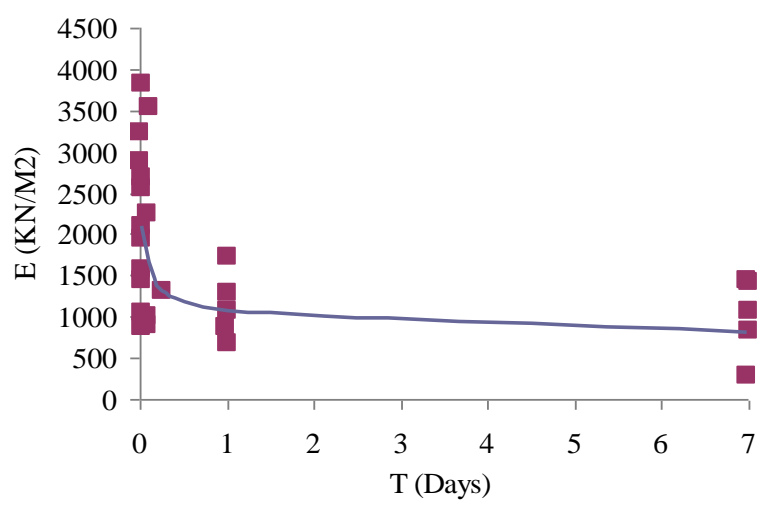

Fig. 4. Variation of Elastic modulus with time delay.

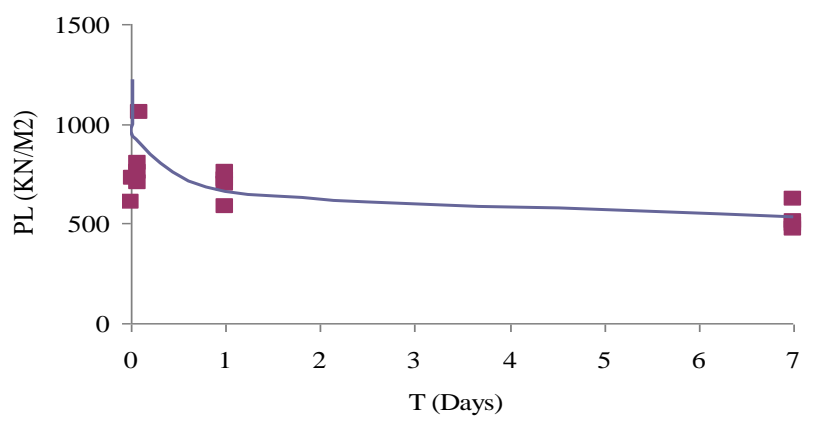

Fig. 5. Variation of conventional limit pressure with time delay.

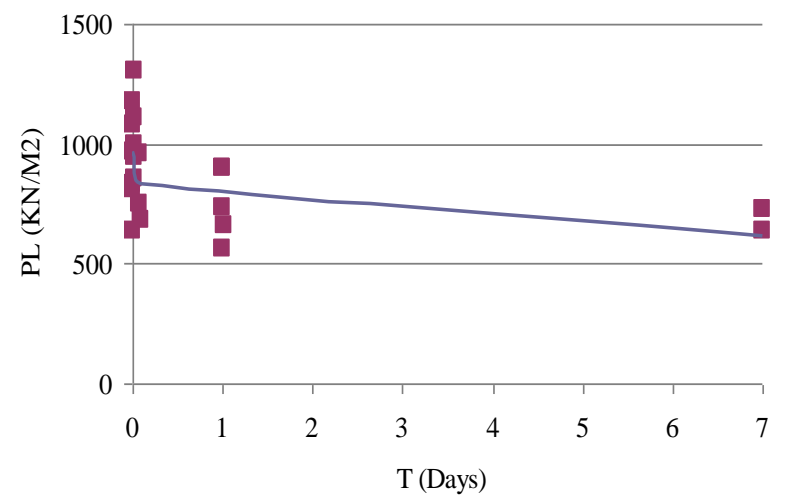

Fig. 6. Variation of theoretical limit pressure with time delay 


\section{The CONVENTIONAL AND THEORETICAL LIMIT PRESSURE}

The values of the conventional limit pressure $\mathrm{P}_{\mathrm{L}}$ deuced for twenty minutes ,two hours ,one day and one week can be seen in Fig. 5, the results suggested that there are little differences between the twenty minutes and two hours tests for $P_{L}$ values. Most of $P_{L}$ values evaluated from one day tests fall in the lower range of those deduced from the twenty minutes tests, but the results of one week tests were much lowers. The results for the theoretical limit pressure are shown in Fig. 6 the tests were conducted after twenty minutes, two hours, one day and one week, the results also showed a considerable decrease with time, most of $\mathrm{P}_{\mathrm{L}}$ values evaluated from one day tests fall in the lower range of those deduced from the twenty minutes tests and the results of one week tests were much lowers.

\section{VARAition OF MOISTURE CONTENT With TIME}

Samples been taken from the sides of the boreholes with time in order to bring out any significant effects in changing the moisture contents of soil in boreholes. A special tool been manufactured in order to take soil samples from the sides of the borehole wall The moisture content for two hours after boring was not studied since it was found too difficult to penetrate the sampler into the sides of the borehole. The mean values of the moisture content of twenty minutes, one day and one week tests are shown in Fig.7. The results showed that there is a considerable increase in the moisture content with time for the soil in the sides of the borehole. The affects of leaving a borehole open for a time are summarized in Table I

TABLE I: SHOWS THE MEAN UNDRAINED PARAMETER OF THE TWENTY MINUTES TESTS WITH RESPECT TO THOSE EVALUATED FROM THE OTHER TIME DELAY TESTS

\begin{tabular}{|c|c|c|c|}
\hline \multirow{2}{*}{$\begin{array}{l}\mathrm{P}_{\mathrm{O}} \\
\text { Ratios }\end{array}$} & $\mathrm{P}_{\mathrm{O} 1 /} \mathrm{P}_{\mathrm{O} 2}$ & $\mathrm{P}_{\mathrm{O} 1 /} \mathrm{P}_{\mathrm{O} 3}$ & $\mathrm{P}_{\mathrm{O} 1 /} \mathrm{P}_{\mathrm{O} 4}$ \\
\hline & 0.98 & 0.95 & 0.54 \\
\hline \multirow{2}{*}{$\begin{array}{l}\mathrm{Cu} \\
\text { Ratios }\end{array}$} & $\mathrm{Cu}_{1} / \mathrm{Cu}_{2}$ & $\mathrm{Cu}_{1} / \mathrm{Cu}_{3}$ & $\mathrm{Cu}_{1} / \mathrm{Cu}_{4}$ \\
\hline & 1.16 & 1.4 & 2 \\
\hline \multirow{2}{*}{$\begin{array}{l}\text { E } \\
\text { Ratios }\end{array}$} & $\mathrm{E}_{1} / \mathrm{E}_{2}$ & $\mathrm{E}_{1} / \mathrm{E}_{3}$ & $\mathrm{E}_{1} / \mathrm{E}_{4}$ \\
\hline & 1.18 & 1.98 & 2.52 \\
\hline \multirow{2}{*}{$\begin{array}{l}\mathrm{P}_{\mathrm{L}} \\
\text { Ratios } \\
\text { C-method }\end{array}$} & $\mathrm{P}_{\mathrm{L} 1 /} \mathrm{P}_{\mathrm{L} 2}$ & $\mathrm{P}_{\mathrm{L} 1 /} \mathrm{P}_{\mathrm{L} 3}$ & $\mathrm{P}_{\mathrm{L} 1 /} \mathrm{P}_{\mathrm{L} 4}$ \\
\hline & 1.26 & 1.53 & 2 \\
\hline \multirow{2}{*}{$\begin{array}{l}\mathrm{P}_{\mathrm{L}} \\
\text { Ratios } \\
\text { U-method }\end{array}$} & $\mathrm{P}_{\mathrm{L} 1 /} \mathrm{P}_{\mathrm{L} 2}$ & $\mathrm{P}_{\mathrm{L} 1 /} \mathrm{P}_{\mathrm{L} 3}$ & $\mathrm{P}_{\mathrm{L} 1 /} \mathrm{P}_{\mathrm{L} 4}$ \\
\hline & 1.22 & 1.32 & 1.66 \\
\hline \multirow{2}{*}{$\begin{array}{l}\mathrm{P}_{\mathrm{L}} \\
\text { Ratios } \\
\text { T-method }\end{array}$} & $\mathrm{P}_{\mathrm{L} 1 /} \mathrm{P}_{\mathrm{L} 2}$ & $\mathrm{P}_{\mathrm{L} 1 /} \mathrm{P}_{\mathrm{L} 3}$ & $\mathrm{P}_{\mathrm{L} 1 /} \mathrm{P}_{\mathrm{L} 4}$ \\
\hline & 1.26 & 1.53 & 2 \\
\hline
\end{tabular}

$1=$ refer to parameters deduced from the twenty minute tests

$2=$ refer to parameters deduced from the two hours tests

$3=$ refer to parameters deduced from the one day tests

$4=$ refer to parameters deduced from the one week tests

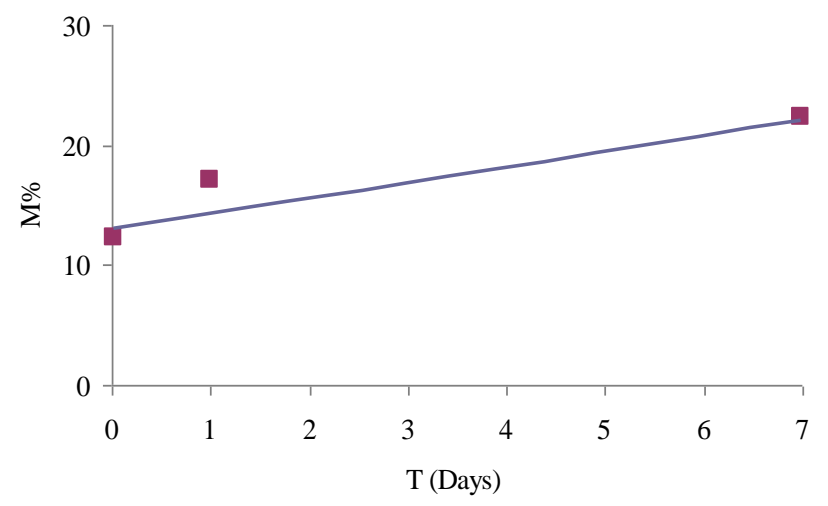

Fig. 7. Variation of the moisture content with time.

\section{CONCLUSIONS}

The present research focused on the effects of time delay between drilling and testing for pressuremeter tests, the research concluded that there is a considerable effects of different parameters deduced from a pressuremeter test. Based on the present research results, some conclusions can be drawn as follow:

1) The values of the horizontal at rest pressure (Po) tend to increase with delay time between boring and pressuremeter testing.

2) The values of the undrained shear strength, Elastic modulus and the limit pressure, showed marked reduction with time delay between boring and pressuremeter testing.

3) A considerable increase in the moisture content was recorded of the soil of the side of borehole wall with increasing of time delay between boring and pressuremeter testing.

4) The effect of time delay may attributed to stress relief and resulting inbibing of water to the soil around the borehole.

5) It is recommended to conduct pressuremeter testing for the soil as soon after completion of the boring.

\section{REFERENCES}

[1] M. Tarnawski, "The perfect m'enard pressuremeter curve," Archives of Hydro-Engineering and Environmental Mechanics, vol. 51, no. 4, pp. 387-402, 2004.

[2] V. Silvestri, "Assessment of self-boring pressuremeter tests in sensitive clay," Canadian Geotechnical Journal, vol. 40, no. 2, pp. 365-38, 2003.

[3] Monnet, J18ème Congrès Français de Mécanique Grenoble, pp. 2731, 2007.

[4] R. Bahar, N. Alimrina, and O. Belhassani," Interpretation of a pressuremeter test in cohesive soils," in Proc. International Conference on Geotechnical Engineering, Tunis, 2013.

[5] R. Bahar and G. Olivari, "Analyse de la réponse du modèle de Prager généralisé sur chemin pressiométrique," Actes du Gème Colloque Franco-Polonais de Mécanique des Sols Appliquée, pp. 97-104, Douai , France, 1993.

[6] L. Ménard, "Mesures in situ des propriétés physiques des sols," Annales des Ponts et Chaussées, pp. 357-376, 1957.

[7] S. Amar and J. F. Jézéquel, "Essais en place et en laboratoire sur sols cohérents: Comparaison des résultats, bulletin de liaison des ponts et chaussées," vol. 58, pp. 97-108, 1972.

[8] X. Rui, Z. Rui-Bin, Y. Ai-Wu, L. Qiang, and C. Feng, "Initial horizontal stress and ko using self-boring pressuremeter," China Harbour Engineering, vol. 1, 2011.

[9] R. M. Alzubaidi, "Pressuremeter practice in testing glacial till," PhD, Thesis, civil Engineering, University of Strathclyde, UK,1984. 
[10] V. A. Wambeke, D. Hericourt, and J Coubed, "Pressiometriques inverses: Méthode d interpretation de lessai pressiometrique," SoilsSoils, vol. 25, pp. 15-25,1975

Radhi Alzubaidi is an associate professor. He obtained his $\mathrm{PhD}$ in geotechnical engineering from University of Strathclyde $-\mathrm{UK}$ in 1984 . His BSc is in civil Engineering from University of Basra-Iraq. The major area of interested research are devoted to in-situ testing and especially the pressuremeter. He has about 25 years experience in academic as a faculty and dean of Engineering School also spend 8 years in industry as a consultant for construction major projects in UAE .
Now he is a faculty in civil and environmental engineering, College of Engineering and also a director for continuous education at University of Sharjah. 